\title{
THE USE OF INLAY PATTERN RESIN AS AN ABUTMENT CROWN TEMPLATE FOR REMOVABLE PARTIAL DENTURES: CLINICAL REPORT
}

\author{
(PENGGUNAAN POLA RESIN INLAY SEBAGAI MODEL TIRUAN MAHKOTA GIGI \\ PENYANGGA PADA PEMBUATAN GIGI TIRUAN SEBAGIAN LEPASAN: LAPORAN KASUS)
}

\author{
Silvia Naliani", Setyawan Bonifacius ${ }^{* *}$, Hadisusanto Ali Martono ${ }^{* * * *}$ \\ *Department of Prosthodontic \\ Faculty of Dentistry, Maranatha Christian University Bandung, Indonesia \\ ** Department of Prosthodontic \\ Faculty of Dentistry, Universitas Padjadjaran Bandung, Indonesia \\ **** Faculty of Dentistry, Maranatha Christian University Bandung, Indonesia \\ Email: silvianaliani@gmail.com
}

\begin{abstract}
Patients with removable partial denture need abutment tooth as retainer for the clasp. In some cases, this tooth requires endodontic treatment or even jacket crown so it can be used as a clasp retainer. For patient with removable partial denture, post core and crown fabrication in abutment teeth require adjustments to the crown to fit with denture clasp. First case, a 23-year-old male patient with fractured lower second premolar tooth because of previous metal restoration failure and had been treated with root canal treatment. The tooth was used as an abutment for removable partial denture that was still in good condition. The tooth was later treated with cast post and core with PFM (Porcelain fused to metal) crown. Second case, a 60-year-old female patient came to the clinic with a complaint of fracture in upper first premolar. This tooth was also used as abutment for maxillary framework partial denture. A template made of pattern resin was made to reproduce the dentures for both cases. Acrylic resin has good accuracy and stability to reproduce parts of the denture. The advantage of this technique is that patients can use their denture during fabrication of the crown.
\end{abstract}

Keywords: post core, jacket crown, resin template, removable partial denture.

\begin{abstract}
Abstrak
Pasien yang menggunakan gigi tiruan lepasan sebagian memerlukan gigi penyangga sebagai tempat cangkolan gigi tiruan. Pada beberapa kasus, gigi penyangga ini memerlukan perawatan endodontik maupun pembuatan mahkota penuh agar masih bisa digunakan sebagai penyangga untuk gigi tiruannya. Bagi pasien dengan gigi tiruan sebagian lepasan, pembuatan pasak dan mahkota penuh pada gigi penyangga memerlukan perawatan sehingga bisa disesuaikan dengan cangkolan gigi tiruannya. Kasus pertama, pria 23 tahun datang dengan keluhan gigi premolar kedua bawah kiri rusak karena fraktur pada amalgam dan gigi tersebut sudah dirawat endodontik sebelumnya. Gigi ini merupakan gigi penyangga untuk gigi tiruan sebagian lepasan bawah akrilik. Gigi tersebut kemudian dibuatkan pasak dan mahkota PFM (Porcelen fused to metal). Kasus kedua, wanita 60 tahun datang dengan keluhan patah pada gigi premolar pertama atas. Gigi ini digunakan juga sebagai penyangga untuk gigi tiruan kerangka logam rahang atas. Suatu tiruan dibuat dari pola resin untuk meniru gigi tiruan pada kedua kasus. Resin akrilik yang digunakan mempunyai keakuratan dan stabilitas untuk meniru bagian-bagian dari gigi tiruan. Keuntungan dari menggunakan teknik ini adalah pasien masih dapat menggunakan gigi tiruannya selama kita membuatkan mahkota.
\end{abstract}

Keywords: post core, jacket crown, resin template, removable partial denture.

\section{INTRODUCTION}

Crowns or other restorations fabricated in order to repair damaged abutment tooth to adjust to an existing removable partial denture is considered a complicated procedure. ${ }^{1}$ Patients often refuse to fabricate new removable partial denture (RPD) or had it taken out during treatment when the abut- 
ments were damaged while the RPD was still usable.

There are several types of plastics which are also known as polymers used in prosthetic dentistry, including acrylic and rubber-reinforced acrylic polymers. Out of all plastic polymers used in the field of prosthetics, acrylic comprises $95 \%{ }^{2}$ Die fabrication technique for fixed or removable denture can be simple, accurate and reliable ${ }^{1,3}$. Resin copings made from inlay resin pattern are used to record the space between the teeth and RPD clasp, assist in occlusal registration, verify the dimensional accuracy of the dies and visualize the marginal adaptation of the retainers. ${ }^{3}$ An existing method to fabricate abutment teeth of previously existed RPD is by using inlay resin pattern to duplicate RPD clasp assembly which will later be transferred to working cast. The replica will merge with the working cast as a removable component and assists in contouring the crown. ${ }^{4}$

\section{CLINICAL REPORT}

A 23-year-old male patient with difficulty in eating as a result of fractured mandibular left second premolar because of previous metal restoration (amalgam) failure which had been treated with root canal treatment came to Maranatha Dental Hospital for consultation regarding available treatment options. A clinical examination revealed that the mandibular left second premolar was used as the abutment for his acrylic removable partial denture, which was still in good condition. He was using removable partial denture (RPD) to replace the missing mandibular right and left molars. Discussion result showed that the patient wanted a strong restoration to replace his fractured tooth and declined a new RPD. Post and core crown were planned to replace the fractured tooth.

Diagnostic cast revealed a short tooth (mandibular left second premolar height was $2 \mathrm{~mm}$ ). The tooth was prepared to remove the remaining dentin (Fig. $1)$.

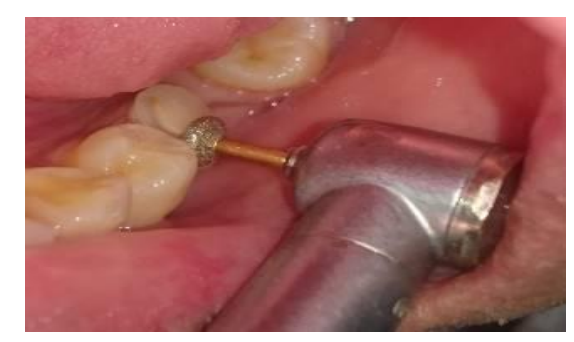

Figure 1. Abutment preparation for post
The gutta percha was removed, then an impression of the root canal was made with PVS and sent to laboratory for post fabrication. The post was tried in and inserted (Fig. 2),

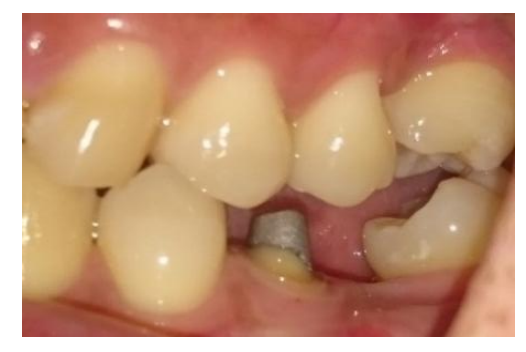

Figure 2. Post insertion

Then, an acrylic template resin was made (Fig. 4) after bite registration using PVS with the RPD in the patient (Fig. 3).

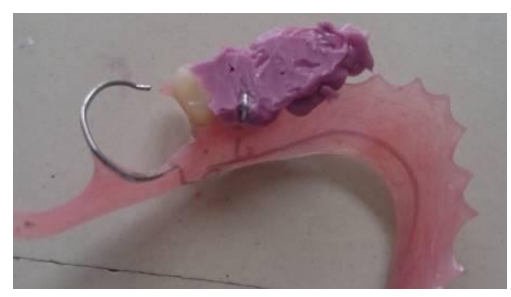

Figure 3. Bite registration using PVS

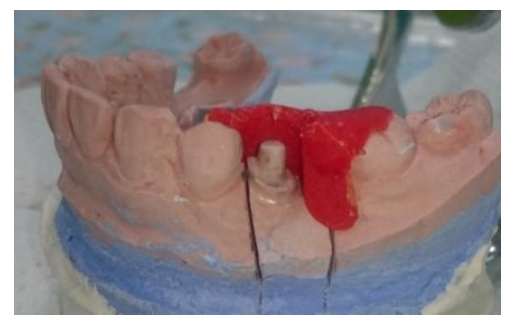

Figure 4. Die and resin template

PFM crown was made using die and acrylic resin template as a guideline, then the crown was inserted (Fig. 5)

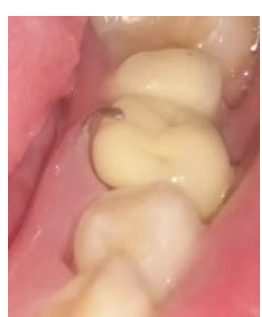

(a)

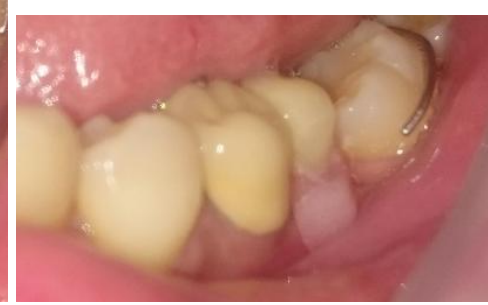

(b)
Figure 5. Crown insertion, (a) occlusal and

(b) lateral view.

A 60-year-old female patient presented to Department of Prosthodontic, Padjadjaran University Den- 
tal Hospital with fractured of left maxillary second premolar filling (Fig. 6).

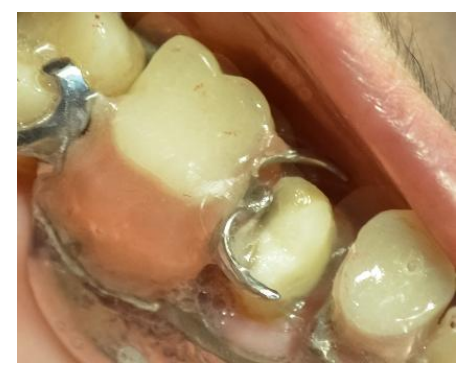

Fig 6. Preoperative view

She reported difficulty in masticating. The tooth was also used as an abutment for maxillary framework partial denture. The patient refused to lend her RPD during treatment. Full crown was indicated because the fracture was large.

After preparation for the full crown is finished, the working model was made. Acrylic resin template (Duralay) was made in the prepared tooth die (Fig. 7) as the abutment for polyether bite registration material (Ramitec, 3M).

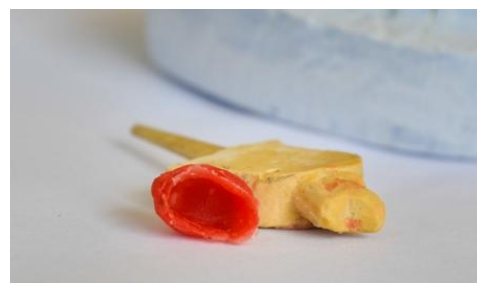

Fig 7. Resin coping

The acrylic resin template was tried in (Fig. 8).

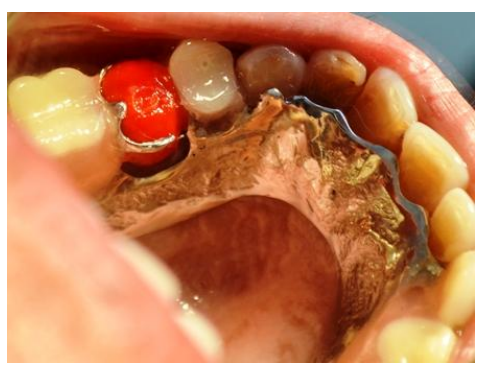

Fig 8. Resin coping try-in

Bite registration was made to duplicate clasp contour (Fig. 9).

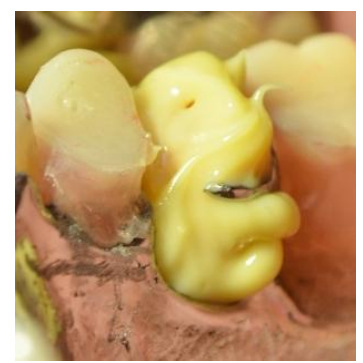

Fig 9. Bite registration

Used the same acrylic resin template (Duralay) to duplicate the clasp (Fig. 10).

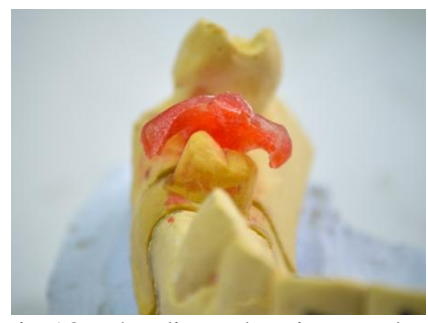

Fig 10. The die and resin template

The crown was made with the resin template used as a guide (Fig. 11).

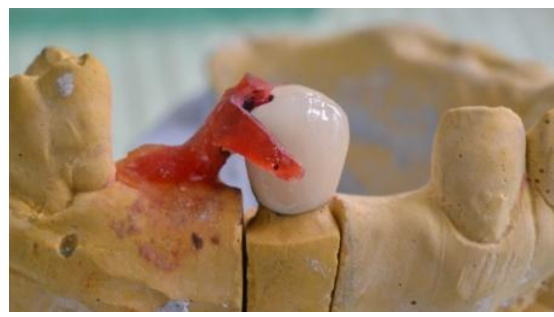

Fig 11. Crown and resin template

Crown was tried in the mouth (Fig. 12) and was inserted after glazing (Fig. 13).

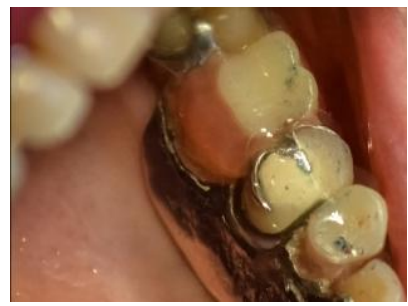

Fig 12. Crown try in 


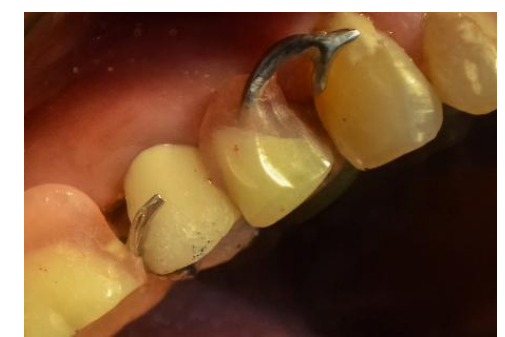

Fig 13. Crown insertion

\section{DISCUSSION}

Acrylic polymers has been widely used in prosthetic dentistry as denture base, artificial teeth, denture repair material, impression tray, provisional restoration, and maxillofacial prosthetics. ${ }^{5}$ Inlay pattern resin (Duralay) usage ensures no breakage, chipping, distortion or temperature changes during trimming, handling, and investing due to its dense, accurate, and non-shrinking pattern. ${ }^{6}$ The cast should be attached to the same maxillary mandibular pretreatment relationship if the goal of restorative treatment is to maintain patient intercuspation and preexisting occlusal dimensions after crown preparation. In order to accurately mount working and opposing cast, acrylic resin transfer copings on top of prepared teeth is used to record the relationship. ${ }^{7}$

Post core crown, full crown or other restoration methods can be used as prosthetic treatment for RPD abutment or fixed denture. There are 3 techniques in fabricating crown fitting the partial denture, i.e. direct, indirect, and combination. Acrylic resin and inlay wax are often used in direct technique in mouth to make a custom pattern which can

\section{REFERENCES}

1. Marchack BW, Chen LB, Marchack CB, Futatsuki Y. Fabrication of an all ceramic abutment crown under an existing removable partial denture using cad/cam technology. J Prosthet Dent 2007; 98(6): 472-8.

2. Robert C, William O, John P. Dental materials properties and manipulation. $6^{\text {th }}$ ed., St. Louis: Mosby, 1996: 242-55.

3. Zuckerman GR. Dies with resin copings for accurate registrations. J Prosthet Dent 1992; 67(1): 37-40.

4. Livaditis GJ. Fabricating abutment crowns for existing removable partial dentures using custom resin clasp analogs. J Prosthet Dent 1998; 80(5): 619-29.

5. John P, Ronald S. Craig's restorative dental materials. $12^{\text {th }}$ ed., St.Louis: Elsevier, 2006: 1-632 reproduce the contour of clasps. Indirect technique uses pick-up impression to produce crown pattern from wax adjusted to denture framework. Combination techniques is a combination of both direct and indirect technique. ${ }^{8}$

Preliminary resin pattern was made directly to the teeth and contouring was done using wax on the working cast in direct-indirect technique. A crown pattern on a die was made and adjusted inside the mouth or on the die after previously tried in the mouth. ${ }^{8}$

Addition silicone and polyether have been used as occlusal registration materials. Both materials have short working time and longer time inside mouth compared to other elastomer impression materials. These materials also have high stiffness and low strain during compression, lower flow and no dimensional changes. ${ }^{5}$ Both cases in this report uses addition silicone and polyether, in which the first case used the former and the second case used the latter. The difference between addition silicone and polyether is that the former has low dimensional changes after removal. ${ }^{5}$

\section{CONCLUSION}

The use of inlay pattern resin as coping and duplication of the clasps of removable partial denture is a simple and accurate technique. A replica of the clasp assembly can be generated and transferred to a traditional working cast as a guideline for crown fabrication, therefore the RPD can still be used by the patient during treatment.

6. Duralay inlay pattern resin. <https://www.darby dental.com/Scripts/prodpage.aspx?CAT=7\&SUB=1 35\&GRP=8830630> (2 September 2017)

7. Antonelli J, Hottel TL, Siegel SC, Darnell L. The acrylic resin transfer coping technique for making accurate interocclusal records. J Tenn Dent Assoc 2011; 91(2): 17-21.

8. Macpherson JR, Evans DB. Fabricating crowns to fit existing removable partial dentures: an illustrations of two techniques. J Prosthodont 1993; 2(3): 199-209. 